21. Obtained from Buchler Instruments, N. J.

22. Kieselguhr G (Merck) obtained from Anderman \& Co., Ltd., East Molesey, Surrey, U. K.

23. The authors are grateful to $P$. Turner for bacteriologic analyses

24. This work was supported by a grant from the Cystic Fibrosis Research Trust. The authors are grateful to Professor C. M. Anderson for encouragement and to

Copyright (c) 1975 International Pediatric Research Foundation, Inc.
Drs. M. Goodchild, M. Brueton, and N. Evans for assistance in obtaining specimens.

25. Requests for reprints should be addressed to: F. A. McEvoy, Ph.D., Department of Biochemistry, School of Biological Sciences, University of Sussex, Falmer, Brighton, Sussex, (U. K.)

26. Accepted for publication May 8, 1975

Pediat. Res. 9: 724-729 (1975)

$\epsilon$-Amino caproic acid

cystic fibrosis

degranulation of leukocytes

enzymes

Printed in U.S.A.

\title{
Demonstration of Human Leukocyte Degranulation Induced by Sera from Homozygotes and Heterozygotes for Cystic Fibrosis
}

\author{
ELAINE J. CONOD, (32) JAMES H. CONOVER, AND KURT HIRSCHHORN \\ Department of Pediatrics, Division of Medical Genetics, Mount Sinai School of Medicine of the City Universitv \\ of New York, New York, New York, USA
}

Extract

The ability of $\epsilon$-amino caproic acid (EACA)-treated normal serum and of cystic fibrosis (CF)-affected and carrier sera to promote the release of Iysosomal enzymes from sensitized human polymorphonuclear leukocytes (PMN) was assessed through the measurement of $\beta$-glucuronidase and myeloperoxidase acitivity after exposure of these cells to the various test sera. This study was initiated to extend the analogies between preciliary dyskinesia factor (pre-CDF), separated from the cell-free media of cultures derived from CF homozygous and heterozygous individuals, and C3a anaphylatoxin. The extent of lysosomal degranulation of human PMN exposed to fresh untreated sera of each of five controls, seven CF homozygotes, and eight heterozygotes, as expressed by the amount of $\beta$-glucuronidase released, was $7.84 \%( \pm \mathbf{0 . 9 3 4})$ for control sera, $14.01 \%( \pm 1.79)$ for CF-affected sera, and $10.61 \%$ $( \pm 1.43)$ for heterozygous sera. The difference between $\mathrm{CF}$ homozygotes and control subjects is significant $(P<0.001)$, as is the difference between CF-affected and carrier individuals $(0.001<P$ $<0.005)$ and between control subjects and carriers $(0.001<P<$ 0.005 ), when $\beta$-glucuronidase release is measured. Analogously, values of myeloperoxidase released by the three groups studied reflect differences similar to those of $\beta$-glucuronidase. However, the differences between control subjects and $C F$ heterozygous individuals are not significant. Treatment of these sera with $1 \mathrm{M}$ EACA gave values for $\beta$-glucuronidase and myeloperoxidase release which are slightly reduced when compared with those obtained with fresh, untreated samples. EACA apparently reduces the activity of $\beta$-glucuronidase released from PMN. Amicon filtration studies of these serum samples demonstrated that degranulating ability and the presence of ciliary dyskinesia, as assessed by rabbit tracheal bioassay, are not always associated. Therefore, the relationship between pre-CDF and the degranulator activity in native $\mathrm{CF}$-affected and carrier sera is unclear, in part because of the limitations inherent in the test systems employed.

\section{Speculation}

The pathophysiology of $C F$ can be explained by excessive degranulation of exocrine glandular cells, resulting in inspissation of their ducts. The finding of degranulator molecules in CF sera allows for a test of this hypothesis. The possibility exists that this degranulating activity, as well as the molecules responsible for ciliary dyskinesia, whether they are the same or different molecular species, may represent an excess of normal products. These molecules, related to $\mathrm{C} 3 \mathrm{a}$ anaphylatoxin and/or kinins, are present in excess in $C F$ because of the deficiency of an enzyme which normally controls their level by inactivation.

Cystic fibrosis is an autosomal recessive disorder occurring predominantly in children and young adults in the Caucasian population. The presence of material in the serum of CF patients which produces dyskinesia in the normal beating pattern of rabbit tracheal cilia was first described by Spock and his associates (18). This ciliary dyskinesia factor (CDF) was found in sera of both CF-affected individuals and obligate heterozygotes for CF. These observations were confirmed in our laboratory using a modification of Spock's original assay system (8), and by Bowman and coworkers (3) using oyster gill preparations in place of the rabbit tracheal explants. This CDF has also been demonstrated to be present in the cell-free medium obtained from phytohemagglutinin-stimulated leukocytes of CF patients and their parents, as well as in the cell-free medium of long term lymphoid lines derived from CF-affected and carrier subjects (7). In addition, the cell-free medium from cultured skin fibroblasts from homozygotes and heterozygotes for $C F$ demonstrates CDF in both the oyster gill system (10) and the rabbit tracheal bioassay system, the latter in the presence of human immunoglobulin $(\operatorname{lgG})(2)$. Previous reports from our laboratory have indicated that the substance responsible for the pathophysiology of CF may be the complement component $\mathrm{C} 3 \mathrm{a}$ anaphylatoxin or a $\mathrm{C} 3 \mathrm{a}-\mathrm{dike}$ molecule (9). Among other properties, anaphylatoxins have been shown to interact with human PMN treated with cytochalasin B, a fungal metabolite, and to promote extracellular release of lysosomal enzyme from these cells $(14,15)$.

Based on analogies drawn between C3a and pre-CDF (9) and on the above findings concerning anaphylatoxins (14), as well as on the known similarities between the biologic activities of $\mathrm{C} 3 \mathrm{a}$ and $\mathrm{C} 5$ a anaphylatoxins, the native degranulating ability of sera from 
$\mathrm{CF}$ and $\mathrm{CF}$ carrier subjects was investigated, as well as the ability of EACA to generate a leukocyte degranulator from normal serum. Attempts were also made to establish the relationship of the degranulator molecular species to those found to be responsible for ciliary dyskinesia.

\section{MATERIALS AND METHODS}

\section{SERUM ENZYME ASSAYS}

Ten milliliters of venous blood was drawn from each of seven $C F$-affected individuals, eight obligate heterozygotes for $\mathrm{CF}$, and five control subjects ascertained previously not to contain $\mathrm{CDF}$ in their serum. (21). The blood was allowed to clot at $4^{\circ}$ and, after clot retraction, centrifuged at $850 \times g$ for $10 \mathrm{~min}$. The serum was collected and an aliquot of each serum sample was assayed for $\beta$-glucuronidase (4) and myeloperoxidase (20). Sera from three control subjects, five $\mathrm{CF}$-affected, and three carrier individuals were made $1 \mathrm{M}$ with EACA (21) and again assayed for $\beta$-glucuronidase (EC. 3.2.1.31) and myeloperoxidase (EC. 1.11.1.7).

\section{PREPARATION OF POLYMORPHONUCLEAR LEUKOCYTES}

Venous blood from normal donors was drawn in heparin (10 $\mathrm{U} / \mathrm{ml})(22)$ and immediately added to $1 / 4$ volume of $6 \%$ dextran in saline $(0.9 \%)$. It was found to be convenient to draw $40 \mathrm{ml}$ blood and add it to $10 \mathrm{ml}$ dextran. The blood-dextran mixture was allowed to sediment at room temperature for $30-45 \mathrm{~min}$. The leukocyte-rich plasma was then removed and centrifuged at $150 \times$ $g$ for $10 \mathrm{~min}$. The white cell pellet was then resuspended in $8 \mathrm{ml}$ distilled water for hypotonic removal of erythrocytes, followed by the addition of $4 \mathrm{ml} 3.6 \%$ saline solution and mixed for a few seconds to restore isotonicity. This solution was then centrifuged at $800 \mathrm{rpm}$ for $10 \mathrm{~min}$, and the resulting pellet washed twice in $0.9 \%$ saline. The final pellet obtained was resuspended in saline to a final concentration of $4 \times 10^{6} \mathrm{PMN} / \mathrm{ml}$.

\section{DEGRANULATION ASSAY}

The degranulation assay employed was essentially that of Goldstein and associates (14) with the modification of increased sample size.

Aliquots $(0.5 \mathrm{ml})$ of a PMN suspension were dispensed into plastic test tubes (23) and incubated with $0.1 \mathrm{ml}$ cytochalasin B solution $(50 \mu \mathrm{g} / \mathrm{ml}$ in $0.1 \%$ dimethylsulfoxide and $0.9 \%$ saline) for $15 \mathrm{~min}$ at $37^{\circ}$. After incubation, $0.2 \mathrm{ml}$ sample was added, and the solution brought to a total volume of $1 \mathrm{ml}$ with Hanks' balanced salt solution (24), and then incubated for $1 \mathrm{hr}$ at $37^{\circ}$. Samples included fresh untreated serum samples, serum samples made $1 \mathrm{M}$ with EACA and incubated for $1 \mathrm{hr}$ at $37^{\circ}$, and heat-inactivated serum samples which were incubated for $1 \mathrm{hr}$ at $37^{\circ}$ without EACA.

After incubation for $1 \mathrm{hr}$ at $37^{\circ}$, the tubes containing PMN and sample were centrifuged at $550 \times g$ at $4^{\circ}$ for $10 \mathrm{~min}$. The cell-free supernatants were removed for enzyme determination. $\beta$ Glucuronidase was determined after $18 \mathrm{hr}$ of incubation with phenolphthalein glucuronidase (21) as substrate (4). Myeloperoxidase was measured as described by the manufacturer of the reagents (20).

The $\beta$-glucuronidase results of the degranulation assay are expressed as percentage of total enzyme activity released by Triton X-100 (21) treatment of $2 \times 10^{6}$ PMN, which causes complete membrane dissolution and release of the entire amount of $\beta$-glucuronidase contained therein. The total $\beta$-glucuronidase activity (TBG) is expressed as micrograms of phenolphthalein per $2 \times 10^{6} \mathrm{PMN}$ per hour. The TBG determinations were made in duplicate each time PMN degranulation was studied, so that each set of results is compared only with the TBG of the respective donor.

Myeloperoxidase results of the degranulation assay are expressed as percentage of total enzyme activity released by sonica- tion of $2 \times 10^{6} \mathrm{PMN}$. The total myeloperoxidase activity (TMP) is expressed as absorbance units at $460 \mathrm{~nm} / 2 \times 10^{6} \mathrm{PMN}$. As with the TBG determinations, the TMP determinations were made in duplicate at the time of each PMN degranulation study.

\section{EACA INHIBITION OF $\beta$-GLUCURONIDASE ACTIVITY OF HUMAN PMN}

Replicate aliquots, each containing $2 \times 10^{6} \mathrm{PMN}$ from a single donor were pipetted into eight tubes. These tubes were centrifuged at $1,600 \mathrm{rpm}$ for $15 \mathrm{~min}$ at $4^{\circ}$, and the supernates were decanted. Each of the pellets was exposed to $0.2 \%$ Triton X-100 (21), either in water or in the presence of varying molarities of EACA for $1 \mathrm{hr}$ at $37^{\circ}$. The cells were again centrifuged and the supernatant assayed for $\beta$-glucuronidase. Absence of EACA represents the total uninhibited enzyme activity in the $2 \times 10^{6} \mathrm{PMN}$.

\section{AMICON FILTRATION STUDIES IN DEGRANULATION ASSAY}

Fresh untreated and $1 \mathrm{M}$ EACA serum samples from two $C F$-affected individuals and two control subjects were collected as described previously and subjected to PM-10 Amicon ultrafiltration (25). Of the PM-10 retentates, $0.2 \mathrm{ml}$, reconstituted to original volume with Hanks' balanced salt solution (24), was tested for its degranulating ability upon exposure to sensitized PMN as described above. In addition, $0.2 \mathrm{ml} \mathrm{PM}-10$ filtrate of each sample was tested for its degranulating ability, with and without the addition of $\mathrm{IgG}$. For the latter experiments, PM-10 filtrates of each sample were collected. To $450 \mu$ l filtrate were added $50 \mu 1$ pooled purified human $\operatorname{IgG}(1 \mathrm{mg} / \mathrm{ml})(26)$ and the mixture was incubated for $15 \mathrm{~min}$ at $37^{\circ}$. The retentate and filtrate fractions, with and without $\operatorname{lgG}$, were also assessed for their ability to promote ciliary dyskinesia in the rabbit tracheal bioassay.

\section{RESULTS}

\section{SERUM ENZYME ASSAYS}

Serum $\beta$-glucuronidase levels of five control subjects, seven $C F$-affected, and eight $C F$ obligate heterozygotes are given in Table 1. Extensive overiapping of serum $\beta$-glucuronidase levels demonstrates that there is no significant difference between these three categories. Similarly, Table 1 illustrates no differences in serum myeloperoxidase levels between controls subjects, $\mathrm{CF}$. affected individuals, and obligate heterozygotes for $\mathrm{CF}$.

Sera from three control subjects, five CF-affected, and three carrier individuals were assayed for both $\beta$-glucuronidase and myeloperoxidase before and after treatment with $1 \mathrm{M}$ EACA. The values obtained for $\beta$-glucuronidase are given in Table 2 and show that EACA causes a diminution of $\beta$-glucuronidase activity in all instances. The mean reduction observed with this enzyme is $49.7 \%$. Similar results were obtained with myeloperoxidase in EACAtreated serum.

\section{DEGRANULATION ASSAY}

The extent of lysosomal degranulation of human PMN exposed to $0.2 \mathrm{ml}$ fresh, untreated serum of each of five control subjects, seven $C F$ homozygotes, and eight $C F$ heterozygotes is given in Table 3. The mean percentage of $\beta$-glucuronidase released from human PMN exposed to control untreated sera is $7.84 \%( \pm 0.934)$, to $\mathrm{CF}$ untreated sera, $14.01 \%( \pm 1.79)$, and to $\mathrm{CF}$ carrier sera, $10.61 \%( \pm 1.43)$. By Student's $t$-test, the mean difference between $\mathrm{CF}$ homozygotes and control subjects is significant $(P<0.001)$. Similarly, the difference between the mean of CF carriers and control subjects is significant $(0.001<P<0.005)$, as is that between CF-affected subjects and carrier subjects $(0.001<P<$ 0.005 ).

The mean percentage of myeloperoxidase released from human PMN exposed to control untreated sera is $3.9 \%( \pm 0.943)$, to CF untreated sera, $7.67 \%( \pm 1.07)$, and to $\mathrm{CF}$ carrier sera, $4.66 \%$ $( \pm 0.70)$. By Student's $t$-test, the mean difference between CF and 
Table 1. Serum $\beta$-glucuronidase and myeloperoxidase levels

\begin{tabular}{ccc}
\hline Subject ${ }^{1}$ & $\begin{array}{c}\mu \text { g phenol- } \\
\text { phthalein } / \mathrm{ml} \\
\text { serum } / \mathrm{hr}^{2}\end{array}$ & $\begin{array}{c}\Delta \mathrm{A} . \mathrm{U} . / \mathrm{ml} \\
\text { serum }^{3}\end{array}$ \\
\hline$N-1$ & 5.15 & 293 \\
$N-2$ & 3.60 & 190 \\
$N-3$ & 3.20 & 275 \\
$N-4$ & 2.15 & 320 \\
$N-5$ & 3.00 & 475 \\
& & \\
$C F-1$ & 4.40 & 720 \\
$C F-2$ & 5.00 & 440 \\
$C F-3$ & 4.25 & 350 \\
$C F-4$ & 2.90 & 260 \\
$C F-5$ & 4.65 & 400 \\
$C F-6$ & 5.25 & 410 \\
$C F-7$ & 8.05 & 475 \\
& & \\
$O H-1$ & 4.63 & 290 \\
$O H-2$ & 2.10 & 295 \\
$O H-3$ & 3.65 & 735 \\
$O H-4$ & 3.60 & 185 \\
$O H-5$ & 7.65 & 340 \\
$O H-6$ & 7.10 & 320 \\
$O H-7$ & 3.10 & 430 \\
$O H-8$ & 3.05 & 530 \\
\hline & -25 & \\
\hline
\end{tabular}

' $\mathrm{N}$ : normal control; $\mathrm{CF}$ : cystic fibrosis patient; $\mathrm{OH}$ : $\mathrm{CF}$ obligate heterozygote.

${ }^{2}$ Serum samples of $0.2 \mathrm{ml}$ were assayed after $18 \mathrm{hr}$ of incubation with substrate.

${ }^{3} \Delta$ A.U. is the difference of absorbance at $460 \mathrm{~nm}$ between a sample blank and the test sample. Serum samples of $0.2 \mathrm{ml}$ were assayed after 5 min of incubation with substrate.

Table 2. Effect of $\epsilon$-amino caproic acid $(E A C A)$ on serum $\beta$-glucuronidase activity

\begin{tabular}{cccc}
\hline $\begin{array}{c}\text { Case } \\
\text { no. }\end{array}$ & Untreated & $\begin{array}{c}\text { Serum } \\
\text { 1 M EACA }\end{array}$ & $\begin{array}{c}\text { \% Reduc- } \\
\text { tion }^{3}\end{array}$ \\
\hline 1 & 5.15 & 2.65 & 48.5 \\
2 & 3.20 & 1.80 & 43.7 \\
3 & 2.15 & 0.90 & 58.2 \\
4 & 3.60 & 1.85 & 48.5 \\
5 & 4.36 & 2.35 & 45.5 \\
6 & 4.58 & 2.35 & 48.6 \\
7 & 3.65 & 2.10 & 42.5 \\
8 & 3.60 & 1.70 & 52.5 \\
9 & 3.10 & 1.40 & 54.9 \\
10 & 4.30 & 1.95 & 54.5 \\
11 & 7.10 & 3.60 & 49.4 \\
\hline
\end{tabular}

${ }^{1}$ Cases nos. 1, 2, 3: normal control subjects; cases nos. 4, 5, 6, 7, 8: cystic fibrosis (CF)-affected individuals; cases nos. 9, 10, 11: CF obligate heterozygotes.

${ }^{2}$ Values expressed as micrcgrams of phenolphthalein per milliliter of serum per hour.

${ }^{3}$ Percentage of reduction: $1 \mathrm{M}$ EACA serum values/untreated serum values, subtracted from $100 \%$. Mean reduction 49.7 .

control sera is significant $(P<0.001)$, as is the mean difference between $\mathrm{CF}$ and obligate heterozygous individuals $(P<$ $0.001)$. However, controls and obligate heterozygotes, although different in the same direction, do not reach significance $(0.05<P<0.1)$ with regard to myeloperoxidase release. In addition, the percentage of myeloperoxidase released in the three groups studied is much lower than the percentage of $\beta$-glucuronidase released. Increasing the serum sample added to PMN up to $0.8 \mathrm{ml}$ did not increase the values for release of $\beta$-glucuronidase or myeloperoxidase, nor did it widen the difference of percentage of enzyme released between the three groups studied. Attempts at causing serum-induced degranulation of human PMN without cytochalasin B sensitization always resulted in a minimal and inconsistent response. Under the same conditions, there is little or no release of the cytoplasmic enzyme, lactic dehydrogenase, indicating that test sera induce lysosomal enzyme release, not cell lysis.

Aliquots of the same sera were made $1 \mathrm{M}$ with EACA and 0.2 $\mathrm{ml}$ of each examined for their ability to promote PMN degranulation. The values obtained are presented in Table 4 . The mean percentage of $\beta$-glucuronidase released when normal $1 \mathrm{M}$ EACAtreated sera were studied was $7.38 \%( \pm 0.988)$, when 1 M EACA $\mathrm{CF}$ sera were tested, $13.46 \%( \pm 1.6)$, and when $1 \mathrm{M}$ EACA-treated obligate heterozygotes sera were tested, $9.81 \%( \pm 1.41)$. The

Table 3. Enzyme release from normal human polymorphonuclear leukocytes $(P M N)$ exposed to fresh untreated serum

\begin{tabular}{|c|c|c|}
\hline \multirow[b]{2}{*}{ Serum sample ${ }^{1}$} & \multicolumn{2}{|c|}{ Enzyme activity released into supernatant ${ }^{2}$} \\
\hline & $\beta$-Glucuronidase ${ }^{3}$ & Myeloperoxidase $^{4}$ \\
\hline$N-1$ & 7.8 & 3.6 \\
\hline$N-2$ & 8.5 & 4.2 \\
\hline$N-3$ & 6.7 & 3.1 \\
\hline$N-4$ & 9.0 & 5.4 \\
\hline$N-5$ & 7.2 & 3.2 \\
\hline$C F-I$ & 17.0 & 7.3 \\
\hline$C F-2$ & 13.3 & 6.1 \\
\hline$C F-3$ & 14.7 & 9.4 \\
\hline$C F-4$ & 12.2 & 7.9 \\
\hline$C F-5$ & 14.0 & 8.5 \\
\hline$C F-6$ & 11.8 & 6.9 \\
\hline$C F-7$ & 15.1 & 7.6 \\
\hline$O H-I$ & 12.0 & 5.4 \\
\hline $\mathrm{OH}-2$ & 11.4 & 4.7 \\
\hline $\mathrm{OH}-3$ & 10.9 & 5.1 \\
\hline$O H-4$ & 10.7 & 3.9 \\
\hline$O H-5$ & 12.3 & 4.1 \\
\hline$O H-6$ & 7.9 & 4.6 \\
\hline $\mathrm{OH}-7$ & 9.4 & 3.8 \\
\hline$O H-8$ & 10.3 & 5.7 \\
\hline
\end{tabular}

${ }^{1} \mathrm{~N}$ : normal control assessed by bioassay; CF: cystic fibrosis patient; $\mathrm{OH}$ : CF obligate heterozygote.

${ }^{2}$ Expressed as percentage of the total activity released from normal PMN by $0.2 \%$ Triton X-100: $\beta$-glucuronidase, $15.1 \mu \mathrm{g}$ phenolphthalein/ $2 \times 10^{6} \mathrm{PMN} / \mathrm{hr}$; myeloperoxidase, 223.7 absorbance units $/ 2 \times 10^{6}$ PMN. Both values represent the average of two total enzyme determinations on the same PMN population.

${ }^{3}$ Samples were corrected for serum $\beta$-glucuronidase contribution by multiplying the concentration of $\beta$-glucuronidase in each donor serum (micrograms of phenolphthalein per milliliter of serum per hour) by 0.04 and subtracting this value from the experimental result. Mean $\mathrm{N} \beta$ glucuronidase, $7.84 \pm 0.934$ (SEM); Mean CF $\beta$-glucuronidase, $14.01 \pm$ 1.79; Mean $\mathrm{OH} \beta$-glucuronidase, $10.61 \pm 1.43$.

${ }^{4}$ Samples were corrected for serum myeloperoxidase contribution by multiplying the concentration of myeloperoxidase in each donor serum (absorbance units per milliliter of serum) by 0.04 and subtracting this value from the experimental result. Mean $\mathrm{N}$ myeloperoxidase, $3.9 \pm$ 0.943; Mean CF myeloperoxidase, $7.67 \pm 1.07$; Mean $\mathrm{CF}-\mathrm{OH}$ myeloperoxidase, $4.66 \pm 0.70$. 
Table 4. Enzyme release from human polymorphonuclear leukocytes $P M N$ exposed to $1 M$-amino caproic acid (EACA) serum

\begin{tabular}{ccc}
\hline & \multicolumn{2}{c}{ Enzyme activity released into supernatant $^{2}$} \\
\cline { 2 - 3 } Serum sample $^{2}$ & $\beta$-Glucuronidase $^{3}$ & Myeloperoxidase $^{4}$ \\
\hline$N-1$ & 7.2 & 3.4 \\
$N-2$ & 8.1 & 3.9 \\
$N-3$ & 6.1 & 3.0 \\
$N-4$ & 8.6 & 5.2 \\
$N-5$ & 6.9 & 2.9 \\
& & \\
$C F-1$ & 15.9 & 6.9 \\
$C F-2$ & 12.6 & 5.9 \\
$C F-3$ & 14.4 & 9.0 \\
$C F-4$ & 11.8 & 7.2 \\
$C F-5$ & 13.8 & 6.2 \\
$C F-6$ & 11.1 & 7.2 \\
$C F-7$ & 14.6 & \\
& & \\
$O H-1$ & 11.1 & 4.8 \\
$O H-2$ & 10.7 & 4.1 \\
$O H-3$ & 9.7 & 4.9 \\
$O H-4$ & 9.8 & 3.4 \\
$O H-5$ & 11.6 & 3.7 \\
$O H-6$ & 7.1 & 4.1 \\
$O H-7$ & 8.9 & 3.3 \\
$O H-8$ & 9.6 & 5.1 \\
& &
\end{tabular}

${ }^{1} \mathrm{~N}$ : normal control assessed by bioassay; $\mathrm{CF}$ : cystic fibrosis patient; $\mathrm{OH}$ : CF obligate heterozygote.

${ }^{2}$ Expressed as percentage of the total activity released from normal PMN by $0.2 \%$ Triton X-100: $\beta$-glucuronidase, $15.4 \mu \mathrm{g}$ phenolphthalein/ $2 \times 10^{6} \mathrm{PMN} / \mathrm{hr}$; myeloperoxidase, 223.1 absorbance units $/ 2 \times 10^{6}$ PMN. Both Values represent the average of two total enzyme determination on the same PMN population.

${ }^{3}$ Samples were corrected for serum $\beta$-glucuronidase contribution by multiplying the concentration of $\beta$-glucuronidase in $1 \mathrm{M}$ EACA donor serum (micrograms of phenolphthalein per milliliter of serum per hour) by 0.04 and subtracting this value from the experimental result. Mean $\mathrm{N} \beta$-glucuronidase, $7.38 \pm 0.988(\mathrm{SEM})$; Mean CF $\beta$-glucuronidase, $13.46 \pm 1.70 ;$ Mean $\mathrm{OH} \beta$-glucuronidase, $9.81 \pm 1.41$.

${ }^{4}$ Samples were corrected for serum myeloperoxidase contribution by multiplying the concentration of myeloperoxidase in each donor serum (absorbance units per milliliter of serum) by 0.04 and subtracting this value from the experimental result. Mean $\mathrm{N}$ myeloperoxidase, $3.64 \pm$ 0.936; Mean CF myeloperoxidase, $7.18 \pm 1.04$; Mean $\mathrm{CF}-\mathrm{OH}$ myeloperoxidase, $4.17 \pm 0.694$.

mean percentage of myeloperoxidase released, under these conditions of EACA treatment, was $3.64 \%( \pm 0.93)$ for control sera, $7.18 \%( \pm 1.04)$ for $\mathrm{CF}$-affected sera, and $4.17 \%( \pm 0.694)$ for $\mathrm{Cr}$ obligate heterozygotes sera. It can be seen that these values are slightly reduced in comparison with those obtained with fresh untreated sera from the same individuals (Table 3 ). Increasing these serum samples up to $0.8 \mathrm{ml}$ also did not increase these values. EACA apparently can reduce the activity of $\beta$-glucuronidase released from PMN, as shown in Figure 1, and as shown above for serum enzyme (Table 2). It can be seen that measured $\beta$-glucuronidase decreases with increasing molarities of EACA.

Other aliquots of these same control, CF, and carrier sera (without EACA) were heat inactivated for $1 \mathrm{hr}$ at $37^{\circ}$ before being assessed for their ability to cause PMN degranulation and concomitant release of lysosomal enzyme. Using $0.2 \mathrm{ml}$ heated sera of each type in the PMN degranulation assay demonstrated an enzyme release pattern very similar to that obtained from fresh, untreated sera in Table 3. Again, increasing the serum samples in each instance up to $0.8 \mathrm{ml}$ failed to change enzyme release in any of the three groups studied.

\section{AMICON FILTRATION STUDIES IN DEGRANULATION ASSAY}

Aliquots of fresh, untreated and $1 \mathrm{M}$ EACA serum samples from two control subjects and two CF-affected individuals were subjected to PM-10 Amicon ultrafiltration. Of each of the PM-10 retentates, $0.2 \mathrm{ml}$ was exposed to sensitized PMN to assess its ability to promote lysosomal degranulation. Of each of the PM-10 filtrates, $0.2 \mathrm{ml}$ was also assessed for the degranulating ability with and without the addition of $\operatorname{IgG}$. $\beta$-Glucuronidase only was assayed in this portion of the study. The results are summarized in Table 5. Control untreated sera subjected to Amicon filtration demonstrated that most of the degranulating ability present in the whole serum was found in the PM-10 retentate fraction, with minimal degranulation demonstrated in the PM-10 filtrate fraction, and only in the presence of $\operatorname{IgG}$.

Untreated CF sera subjected to Amicon filtration demonstrated that most of the degranulating ability of the whole serum again was to be found in the PM-10 retentate fraction with minimal degranulation demonstrated in the PM-10 filtrate fraction, again only in the presence of $\mathrm{IgG}$. Amicon filtration of CF serum made 1 $M$ with EACA showed the degranulating ability to be confined to the PM-10 filtrate fractions, with or without IgG.

CDF bioassay results on these same fractions and serum are also summarized in Table 5. It can be seen that the presence of degranulating ability is not always accompanied by the appearance of a dyskinesia response when samples are placed on rabbit trachea explants. This difference can be seen particularly in the CF PM-10 retentate. The reverse does not preclude a positive bioassay response, as seen particularly in the PM-10 filtrate of the $C F$ EACA-treated samples. Note also that whole normal serum and its $\mathrm{PM}-10$ retentate are negative for CDF activity, whereas EACA-treated normal serum and its $\mathrm{PM}-10$ retentate are $C D F$ positive despite a mild reduction in degranulation activity.

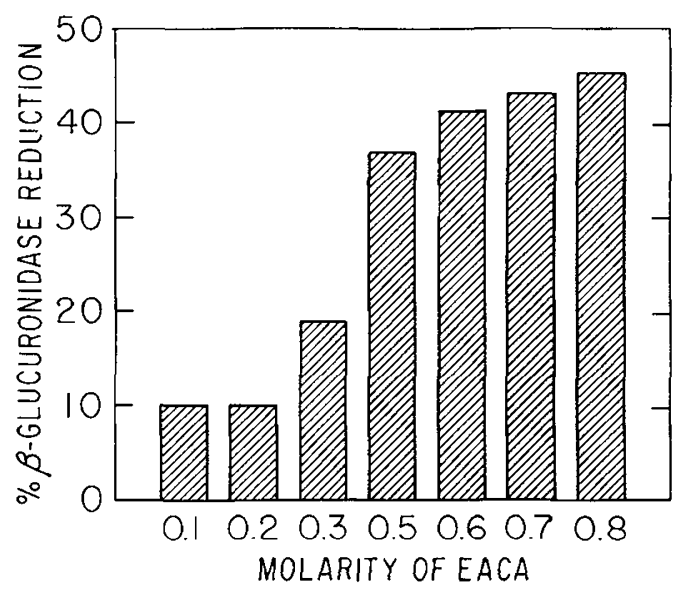

Fig. 1. $\epsilon$-amino caproic acid $(E A C A)$ reduction of $\beta$-glucuronidase activity released from human polymorphonuclear leukocytes (PMN). Replicate aliquots, each containing $2 \times 10^{6} \mathrm{PMN}$ from a single normal donor were pipetted into eight tubes. These tubes were centrifuged at 1,600 rpm for $15 \mathrm{~min}$, and the supernates were decanted. Each of the pellets was exposed to $0.2 \%$ Triton X-100, either in water or in varying molarities of EACA in water for $1 \mathrm{hr}$ at $37^{\circ} \mathrm{c}$. Zero molarity EACA represents the total enzyme activity released from $2 \times{ }^{6}$ PMN. Values of $\beta$-glucuronidase activity obtained after exposure to increasing molarities of EACA are graphically represented. In each instance, the percentage of reduction is derived by dividing the amount of $\beta$-glucuronidase released in the presence of EACA by the total enzyme released without EACA $\times 100$ and substracting the value obtained from $100 \%$. 
Table 5. Comparison of degranulating ability and ciliary dyskinesia factor activity of Amicon filtration fractions ${ }^{1}$

\begin{tabular}{|c|c|c|c|c|c|c|c|c|}
\hline Sample & \multicolumn{2}{|c|}{ Whole serum } & \multicolumn{2}{|c|}{ PM- 10 retentate } & \multicolumn{4}{|c|}{ PM-10 filtrate } \\
\hline Control & $9.0 \%$ & - & $8.6 \%$ & - & - & - & - & - \\
\hline Control/EACA & $8.6 \%$ & + & $5.2 \%$ & + & $1.6 \%$ & + & - & - \\
\hline
\end{tabular}

${ }^{1} \mathrm{DA}$ : degranulating ability; CDF: ciliary dyskinesia factor; EACA: $\epsilon$-amino caproic acid. Control: normal control assessed by bioassay; CF: cystic fibrosis patient; Control/EACA: control serum with $1 \mathrm{M}$ EACA; CF/EACA: CF serum with $1 \mathrm{M}$ EACA. Each value represents the average obtained with two different sera of each class.

${ }^{2}$ Degranulating ability, expressed as percentage of total $\beta$-glucuronidase activity released by $0.2 \%$ Triton X-100 $(14.9 \mu \mathrm{g}$ phenolphthalein/2 $\times$ $10^{6} \mathrm{PMN} / \mathrm{hr}$ ).

${ }^{3}+$ : positive; -: negative.

\section{DISCUSSION}

Previous work in our laboratory has raised the possibility that pre-CDF, the fraction of CDF without $\operatorname{IgG}$, may be analogous to $\mathrm{C} 3 \mathrm{a}$ anaphylatoxin, which in turn may be responsible for the pathophysiology of cystic fibrosis (9).

The anaphylatoxins, C3a and C5a, are relatively low molecular weight substances which are the reaction products of the serum complement system. In releasing histamine through the degranulation of mast cells (6), or lysosomal enzymes from PMN (1), these biologically active molecules cause increased capillary permeability, edema, and contraction of smooth muscle, and are generally considered to be permeability factors similar in activity to the kinins (17).

The known biochemical and physiologic properties of the anaphylatoxins, together with the behavior of $\mathrm{C} 3 \mathrm{a}$, when associated with $\operatorname{IgG}$ in our tracheal bioassay (9), compare favorably with those of molecular species which we have separated from sera and cell culture supernates from cell lines established from CF homozygotes and heterozygotes (2). Sera from normal healthy subjects previously inactive by bioassay for ciliary dyskinesia factor (CDF) could be converted to a CDF-positive activity by incubation with EACA. EACA is a known inhibitor of the carboxypeptidase B-like anaphylatoxin inactivator (16), and incubation with EACA is the method of choice for accumulating anaphylatoxins in normal blood (19). Incubation of EACA-treated normal sera and fresh CDF-positive CF sera with carboxypeptidase $B$ produced reversion in all instances to a $C D F$-negative state, as assessed by rabbit tracheal bioassay (9).

More recently, it has been reported that the anaphylatoxins interact with human polymorphonuclear leukocytes treated with cytochalasin B and promote extracellular release of lysosomal enzymes from these cells $(14,15)$. Cytochalasin B interferes with the function of cytoplasmic microfilaments, causes the movement of lysosomes to the surface of the cell, and inhibits membrane transport of sugars and nucleosides in cultured cells $(5,13)$. By virtue of these effects, cytochalasin B-treated polymorphonuclear leukocytes are unable to phagocytose but selectively extrude lysosomal enzyme when particles come into contact with the cell surface $(11,12)$. Based on the observation that the intracellular events accompanying enzyme discharge from sensitized PMN, for example, membrane fusion, were enhanced by particles which fix complement, Goldstein and his associates studied the interaction between the complement system and the cytochalasin B-treated PMN (15). Results of these experiments indicated that fresh, normal human serum, treated with EACA and zymosan, enhanced lysosomal enzyme release from PMN by facilitating fusion of lysosomes with the plasma membrane. Enzyme release is selective in that it is not accompanied by the release of cytoplasmic enzymes or loss of cellular viability. Untreated normal human serum was ineffective in stimulating the release of enzyme.
In this system, it was concluded that the complement component, C5a, acts as a perturbing agent which causes stable bilayer membranes to become temporarily unstable micellar structures which fuse by compaction with other similarly affected membranes. In these experiments, degranulation properties have been attributed to $\mathrm{C} 5 \mathrm{a}$ in particular, since the inhibition of anaphylatoxin inactivator with EACA in serum was followed by zymosan treatment, which generates both $\mathrm{C} 3 \mathrm{a}$ and $\mathrm{C} 5 \mathrm{a}$. However, it is not difficult to speculate that $\mathrm{C} 3 \mathrm{a}$ may also contribute to the degranulation observed and this possibility has not been excluded completely by Goldstein and his associates $(14,15)$. Treatment of serum with EACA alone will generate C3a (19) and C3a has been demonstrated to participate in mast cell degranulation (6).

Considering the similarities between C3a and pre-CDF (9) and the findings of the above experiments of Goldstein and associates, the PMN degranulation system was employed to study the native degranulating ability of sera from CF and carrier subjects and the role of EACA in generating a leukocyte degranulator from normal serum. Since we wanted to restrict our study to $\mathrm{C} 3 \mathrm{a}$ in the absence of the strongly degranulating $\mathrm{C} 5 \mathrm{a}$, we omitted zymosan treatment of the serum samples. It should be remembered that $\mathrm{C} 3 \mathrm{a}$ is 100-1,000 times less active in promoting degranulation than is C5a (17).

Serum levels of $\beta$-glucuronidase and myeloperoxidase from normal, CF-affected, and CF obligate heterozygous individuals were similar and demonstrated no significant differences in the three groups studied.

Untreated sera from CF patients demonstrated a significant increase in PMN degranulation above values obtained with normal and obligate heterozygote serum samples when $\beta$-glucuronidase and myeloperoxidase release into the supernatant was assessed. Degranulating ability of serum samples from obligate heterozygotes was increased significantly over that of normal control subjects when supernatant $\beta$-glucuronidase was assessed, and also when myeloperoxidase release was measured, but not to a statistically significant level in the case of the latter enzyme.

Treatment of CF-affected, obligate herterozygote, and control sera with 1 M EACA was shown to decrease the amount of $\beta$-glucuronidase activity measured in the sera when compared with untreated sera from the same individuals. In addition, EACA somewhat decreased activity of $\beta$-glucuronidase released by sensitized PMN. Because of these observations, myeloperoxidase was also assayed in the supernatant after exposure of serum sample to PMN. However, a similar trend of reduced enzyme activity was observed in the presence of EACA.

It was hoped originally that through the use of EACA, the analogies drawn between EACA-treated normal serum and $\mathrm{CF}$ serum in the CDF bioassay could be extended to the degranulation of PMN. However, assessment of the degranulating ability of EACA-treated serum served only to retain the differences in degranulation observed with untreated sera in the three groups of 
individuals studied, and most important, did not increase the degranulating ability of normal sera. Therefore, a discrepancy exists between the finding that EACA-treated normal serum demonstrates positive ciliary dyskinesia in the bioassay and the finding that EACA does not apparently increase the degranulating ability of normal whole serum. Heat inactivation has also been shown to accumulate anaphylatoxins in normal human serum in the presence of EACA (19). Again, we did not find an increase of degranulating ability of normal serum in the presence of EACA.

Since EACA treatment or heat inactivation of serum has been shown to accumulate $\mathrm{C} 3 \mathrm{a}$ anaphylatoxins, our studies show that C3a cannot be a potent degranulator of human PMN. Since CF sera do show a marked increase in such degranulating ability, demonstrated to a lesser extent by heterozygous sera, the degranulator in CF probably is not C3a.

In an effort to demonstrate that the degranulating ability of native CF and obligate heterozygous serum could be attributable to a molecule of molecular weight $1,000-10,000$, the weight range determined previously for pre-CDF, Amicon filtration studies were performed.

In view of the differences we have shown in the fractions of serum containing degranulating and CDF activity, respectively, we suggest that the basic defect in CF may be an enzyme which normally inactivates a number of kinin-like molecules, among which are $\mathrm{CDF}$, which may be related to $\mathrm{C} 3$ a anaphylatoxin, and a degranulating factor which may be a different molecule.

Our finding of an increased degranulating ability in CF serum may point to the molecule responsible for degranulation of various exocrine gland cells, a process which could explain most, if not all, of the pathophysiology of the disease.

\section{SUMMARY}

Evidence is presented that CF homozygote and heterozygote sera promote lysosomal degranulation of sensitized human leukocytes, as measured by enzyme release, to a significantly greater extent than normal serum. Attempts to identify the molecular substance responsible for this membrane-associated phenomenon as pre-CDF by Amicon filtration has met with limited success. Thus the analogy between this degranulator and the ciliary dyskinesia factor in CF sera is incomplete, in part because of the limitations inherent in the cellular test system employed. However, the presence of such a degranulator in CF and carrier sera may furnish further explanation of some of the aspects of the pathophysiology observed in cystic fibrosis.

\section{REFERENCES AND NOTES}

1. Becker, E. L., Showell, H. J., Henson, P. M., and Hsu, L. S.: The ability of chemotactic factors to induce lysosomal enzyme release. I. The characteristics of the release, the importance of surface, and the relation of enzyme release to chemotactic responsiveness. J. Immunol., /12: 2047 (1974).

2. Beratis, N. G., Conover, J. H., Conod, E. J., Bonforte, R. J., and Hirschhorn, K.: Studies on ciliary dyskinesia factor in cystic fibrosis. III. Skin fibroblasts and cultured amniotic fluid cells. Pediat. Res., 7: 958 (1973).

3. Bowman, B. H., Lockhart, L. H., and Mccombs, M. L.: Oyster ciliary inhibition by cystic fibrosis factor. Science, 164: 325 (1969).
4. Brittinger, G., Hirschhorn, R., Douglas, S. D., and Weissmann, G.: Studies on lysosomes. XI. Characterization of a hydrolase-rich fraction from human lymphocytes. J. Cell Biol., 37: 394 (1968).

5. Carter, S. B.: Effects of cytochalasin on mammalian cells. Nature, 2/3: 8261 (1967).

6. Cochrane, C. G., and Muller-Eberhard, H. J.: The derivation of two distinct anaphylatoxin activities from the third and fifth components of human complement. J. Exp. Med., 127: 371 (1968).

7. Conover, J. H., Beratis, N. G., Conod, E. J., Ainbender, E., and Hirschhorn, K.: Studies on ciliary dyskinesia factor in cystic fibrosis. II. Short-term leukocyte cultures and long-term lymphoid lines. Pediat. Res., 7: 224 (1973).

8. Conover, J. H., Bonforte, R. J., Hathaway, P., Paciuc, S., Conod, E. J., Hirschhorn, K., and Kopel, F. B.: Studies on ciliary dyskinesia factor in cystic fibrosis. I. Bioassay and heterozygote detection in serum. Pediat. Res., 7: 220 (1973).

9. Conover, J. H., Conod, E. J., and Hirschhorn, K. Studies on ciliary dyskinesia factor in cystic fibrosis. IV. Its possible identification as anaphylatoxin (C3a)-IgG complex. Life Sci., 14: 253 (1974).

10. Danes, B. S., and Bearn, A. G.: Oyster ciliary inhibition by cystic fibrosis culture medium. J. Exp. Med., 136: 1313 (1972).

11. Davies, P., Fox, R. I., Polyzonis, M., Allison, A. C., and Haswell, A. D.: The inhibition of phagocytosis and facilitation of exocytosis in rabbit polymorphonuclear leukocytes by cytochalasin B. Lab. Invest., 28: 16 (1973).

12. Davis, A. T., Estensen, R., and Quie, P. G.: Cytochalasin B. III. Inhibition of human polymorphonuclear leukocyte phagocytosis. Proc. Soc. Exp. Biol. Med., 137: 161 (1971)

13. Estensen, R. D., and Plagemann, P. G. W.: Cytochalasin B: Inhibition of glucose and glucosamine transport. Proc. Nat. Acad. Sci. U. S. A., 69: 1430 (1972).

14. Goldstein, I. M., Brai, M., Oster, A. G., and Weissmann, G.: Lysosomal enzyme release from human leukocytes: Mediation by the alternate pathway of complement activation. J. Immunol., 111: 33 (1973).

15. Goldstein, I., Hoffstein, S., Gallin, J., and Weissmann, G.: Mechanisms of lysosomal enzyme release from human leukocytes: Microtubule assembly and membrane fusion induced by a component of complement. Proc. Nat. Acad. Sci. U. S. A., 70: 2916 (1973).

16. Muller-Eberhard, H. J.: The molecular basis of the biological activities of complement. The Harvey Lectures, p. 75 (Academic Press, New York, 1972).

17. Muller-Eberhard, H. J., Vallota, E. H., Gotze, O., and Zimmerman, T. S.: Mediators of the inflammatory response-complement. In: I. H. Lepow and P. A. Ward: Inflammation: Mechanisms and Control, p. 83 (Academic Press, New York, 1972).

18. Spock, A., Heick, H. M. C., Cress, H., and Logan, W. J.: Abnormal serum factor in patients with cystic fibrosis of the pancreas. Pediat. Res., 1: 173 (1967).

19. Vallota, E. H., and Muller-Eberhard, H. J.: Formation of C3a and C5a anaphylatoxin in whole human serum after inhibition of anaphylatoxin inactivator. J. Exp. Med., 137: 1109 (1973).

20. Worthington Manual of Enzymes Mo. and Enzyme Reagents, Worthington

21. Sigma Chemical Co., St. Louis, Mo.

22. Upjohn, Kalamazoo, Mich.

23. Falcon Plastics, Los Angeles, Calif.

24. Grand Island Biological Co., Grand Island, N. Y.

25. Amicon Corp., Lexington, Mass.

26. Meloy Laboratories, Springfield, Va.

27. The authors are indebted to Dr. Jack Gorvoy and Dr. Carolyn Denning for their contribution of the serum samples used in this study as well as to their patients whose cooperation is acknowledged.

28. Dr. J. H. Conover is a Career Scientist of the Health Research Council of the City of New York (I-804).

29. Dr. K. Hirschhorn is a Career Scientist of the Health Research Council of the City of New York (I-513)

30. This research was supported by grants from the United States Public Health Service (HD-02552 and Genetics Center Grant GM-19443) and from the National Foundation-March of Dimes (I-338).

31. The present address of Drs. E. J. Conod and J. H. Conover is: Department of Pediatrics, Albert Einstein College of Medicine, 1300 Morris Park Ave., Bronx, N. Y. 10461 (USA).

32. Requests for reprints should be addressed to: E. J. Conod, Ph.D., Department of Pediatrics, Albert Einstein College of Medicine, 1300 Morris Park Ave., Bronx, N. Y. 10461 (USA).

33. Accepted for publication May 19, 1975. 